University of Nebraska - Lincoln

DigitalCommons@University of Nebraska - Lincoln

\title{
Depositional History and Neotectonics in Great Salt Lake, Utah, from High-Resolution Seismic Stratigraphy
}

Steven M. Colman

U.S. Geological Survey, 384 Woods Hole Road., Woods Hole, MA 02543, USA

Kerry R. Kelts

Limnological Research Center, University of Minnesota, Minneapolis, MN 55455, USA

David A. Dinter

Department of Geology and Geophysics, University of Utah, 717 WBB, Salt Lake City, UT 84112, USA

Follow this and additional works at: https://digitalcommons.unl.edu/usgsstaffpub

Part of the Earth Sciences Commons

Colman, Steven M.; Kelts, Kerry R.; and Dinter, David A., "Depositional History and Neotectonics in Great Salt Lake, Utah, from High-Resolution Seismic Stratigraphy" (2002). USGS Staff -- Published Research. 277.

https://digitalcommons.unl.edu/usgsstaffpub/277

This Article is brought to you for free and open access by the US Geological Survey at DigitalCommons@University of Nebraska - Lincoln. It has been accepted for inclusion in USGS Staff -- Published Research by an authorized administrator of DigitalCommons@University of Nebraska - Lincoln. 


\title{
Depositional history and neotectonics in Great Salt Lake, Utah, from high-resolution seismic stratigraphy
}

\author{
Steven M. Colman ${ }^{\text {a,*}}$, Kerry R. Kelts ${ }^{\mathrm{b}, 1}$, David A. Dinter ${ }^{\mathrm{c}}$ \\ ${ }^{\mathrm{a}}$ U.S. Geological Survey, 384 Woods Hole Road., Woods Hole, MA 02543, USA \\ ${ }^{\mathrm{b}}$ Limnological Research Center, University of Minnesota, Minneapolis, MN 55455, USA \\ ${ }^{\mathrm{c}}$ Department of Geology and Geophysics, University of Utah, 717 WBB, Salt Lake City, UT 84112, USA
}

Accepted 1 August 2001

\begin{abstract}
High-resolution seismic-reflection data from Great Salt Lake show that the basinal sediment sequence is cut by numerous faults with $\mathrm{N}-\mathrm{S}$ and $\mathrm{NE}-\mathrm{SW}$ orientations. This faulting shows evidence of varied timing and relative offsets, but includes at least three events totaling about $12 \mathrm{~m}$ following the Bonneville phase of the lake (since about $13.5 \mathrm{ka}$ ). Several faults displace the uppermost sediments and the lake floor. Bioherm structures are present above some faults, which suggests that the faults served as conduits for sublacustrine discharge of fresh water. A shallow, fault-controlled ridge between Carrington Island and Promontory Point, underlain by a well-cemented pavement, separates the main lake into two basins. The pavement appears to be early Holocene in age and younger sediments lap onto it. Onlap-offlap relationships, reflection truncations, and morphology of the lake floor indicate a low lake, well below the present level, during the early Holocene, during which most of the basin was probably a playa. This low stand is represented by irregular reflections in seismic profiles from the deepest part of the basin. Other prominent reflectors in the profiles are correlated with lithologic changes in sediment cores related to the end of the Bonneville stage of the lake, a thick mirabilite layer in the northern basin, and the Mazama tephra. Reflections below those penetrated by sediment cores document earlier lacustrine cycles. (C) 2002 Elsevier Science B.V. All rights reserved.
\end{abstract}

Keywords: Great Salt Lake; Seismic-reflection profiles; Sediments; Neotectonics; Paleoclimate

\section{Introduction}

As part of an on-going effort to reconstruct the climatic and neotectonic history recorded in sediments

\footnotetext{
${ }^{*}$ Corresponding author. Tel.: +1-508-457-2341; fax: +1-508457-2310.

E-mail address: scolman@usgs.gov (S.M. Colman).

${ }^{1}$ Kerry passed away while this paper was awaiting publication, after a long battle with cancer. The Great Salt Lake was one of Kerry's career-long interests. This paper is dedicated to his memory.
}

below the Great Salt Lake (Fig. 1), we conducted several high-resolution seismic-reflection surveys, using $3.5 / 7 \mathrm{kHz}$, 'CHIRP', and 'boomer' systems that attained sediment penetrations ranging from 20 to 200 $\mathrm{m}$. The seismic-reflection profiles underpin core site selection and the correlation among sediment core records of paleoclimate from the Great Salt Lake basin. Seismic data also provide direct evidence of climate change, as they can be interpreted to relate to sedimentation patterns, especially those associated with changes in lake level. In addition to paleoclimate evidence, seismic data reveal evidence of recent 


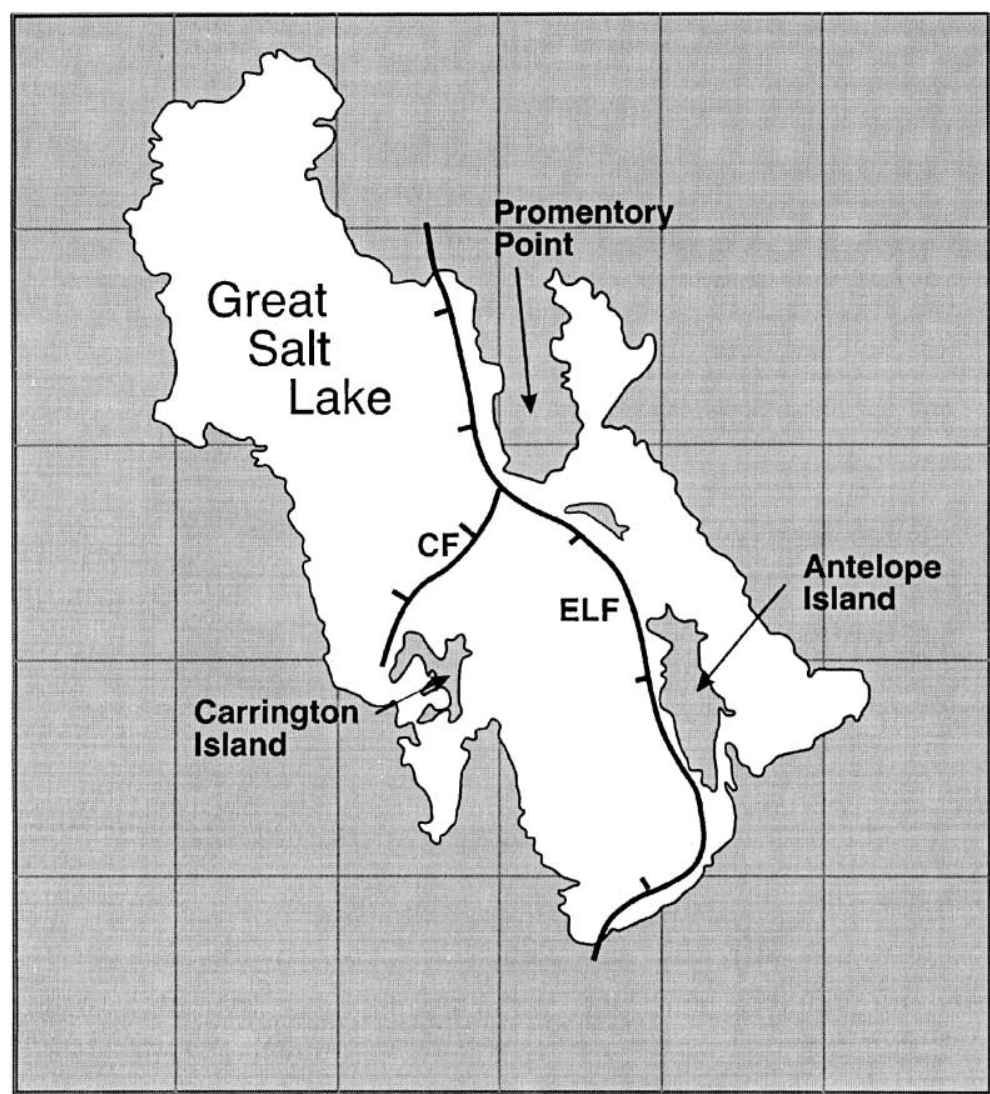

Fig. 1. Map of the Great Salt Lake showing locations mentioned in the text and major faults (modified from Mohapatra and Johnson, 1998) identified from AMOCO seismic data. CF, Carrington Fault; ELF, East Lake Fault.

faulting and deformation of importance to the regional tectonic and depositional history.

Numerous studies have discussed the history of lake level and tectonics in the Great Salt Lake basin, beginning with Gilbert (1890). However, most of these studies examined exposed sediments above present lake level; relatively few have sampled or imaged the sediments below the present lake. Only two significant seismic-reflection surveys pre-date ours. In the 1970s, AMOCO collected an extensive set of multichannel, deep-penetrating (relatively low resolution) profiles as part of a hydrocarbon exploration program. These data have been reanalyzed recently for their large-scale tectonic significance by Mohapatra and Johnson (1998). Mikulich and Smith (1974) collected a suite of single-channel seismic-reflection data in Great Salt
Lake in 1969, using air-gun and sparker systems. Although the records displayed strong multiples, Mikulich and Smith (1974) were able to delineate many of the major structural features beneath the lake, including the East Lake Fault (Antelope Island segment) discussed in this paper.

AMOCO drilled 17 deep holes in Great Salt Lake during their exploration effort. Paleoenvironmental reconstructions based mostly on paleontology and sedimentology of cuttings from three of those drill holes have been published recently by Davis and Moutoux (1998) and Kowalewska and Cohen (1998). A series of cores in the lake and cores from drill holes on the southern margin of the lake were described by Eardley et al. (1973). Finally, as part of our study, several piston cores were collected in the southern 
basin of the lake (Kelts, K.R., Thompson, R.S., and Oviatt, C.G., unpublished data).

Here, we present the results of a single-channel, high-resolution seismic-reflection survey conducted in 1997 in Great Salt Lake south of the railroad causeway (Fig. 2). We also include data from a preliminary seismic survey, conducted in 1979 (Kelts, K.R., unpublished data) as part of the coring project described in Spencer et al. (1984). The limited set of lines acquired in 1979 were reacquired in 1997 (Fig. 2). Finally, we added detail to our maps and interpretations from a set of 'boomer' and 'CHIRP' data collected for paleoseismicity studies by Dinter and
Pechmann (1999a,b) in 1998 along the East Lake Fault (Fig. 2).

\section{Data and methods}

The 1979 survey used a $3.5-7 \mathrm{kHz}$ system, which was custom built, shielded, and tuned to the lake depths by Edo Western, to collect data along survey lines located by horizontal sextant sightings. In July, 1997, we collected seismic-reflection data along the survey lines shown in Fig. 2, located with a militarygrade GPS (Colman and Kelts, 1997). The seismic

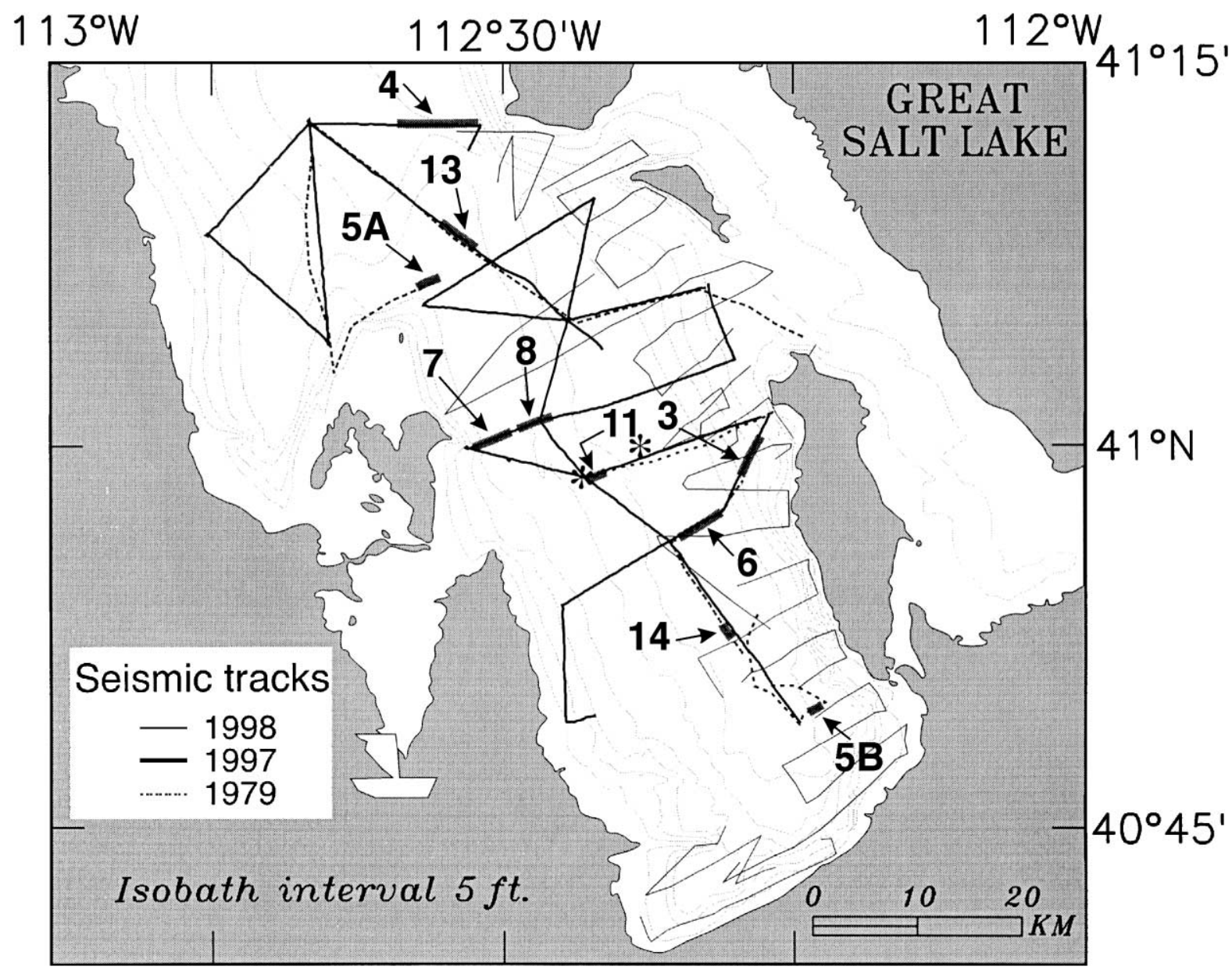

Fig. 2. Map showing the location of seismic survey track lines from 1979 (K.R. Kelts, unpublished data), 1997 (Colman and Kelts, 1997), and 1998 (Dinter and Pechmann, 1999a,b). Seismic profiles shown in this paper are identified by figure number, arrow, and thick segment of track line. Asterisks mark the location of the two cores (core $C$ to the west and core 96-6 to the east) discussed in the text. 
data were collected using two systems: (1) a sidemounted array of four $3.5-\mathrm{kHz}$ transducers, two sending an acoustic pulse (every $0.25 \mathrm{~s}$ ) and two receiving the returns, and (2) a broad-band (ca. 500-5000 Hz) 'boomer' sound source towed behind the boat and fired every $0.5 \mathrm{~s}$; reflections from this second system were received with a 10-element hydrophone streamer and were then amplified and filtered. Raw analog data from both systems were digitally sampled and recorded in SEGY format.

The profiles collected in 1998 along the East Lake Fault were obtained with a 'boomer' and a 'CHIRP' system (Dinter and Pechmann, 1999a,b). These data are not presented here, but are used in some of our maps and interpretations. The depth scales of seismic profiles shown were calculated using a sound velocity of $1500 \mathrm{~m} / \mathrm{s}$. For the water column, this velocity was confirmed with depth measurements to the lake floor and to the top of the brine in the northern basin of the lake. The locations of seismic profiles in the figures of this paper are shown in Fig. 2.

\section{Discussion}

\subsection{Evidence for recent tectonic deformation}

Located along the Wasatch Front, at the eastern edge of the Basin and Range Province, the Great Salt Lake basin is a tectonically active area. Multiple, meter-scale vertical displacements have been documented previously on the Wasatch Fault, east of the lake (c.f., Arabasz et al., 1979). Less well known are the histories of the two faults that lie beneath the southern part of the lake (Fig. 1), although their existence has been known for some time (Mikulich and Smith, 1974; Pechmann et al., 1987). Both modern seismicity and tectonic displacement on large-scale, north-south trending, listric normal faults extend across a wide zone that includes both the Wasatch Front and Great Salt Lake (Smith and Bruhn, 1984; Mohapatra and Johnson, 1998). The East Lake Fault lies along the west edge of Antelope and Free- mont Islands and extends northwestward, following the west side of Promontory Point. The Carrington Fault extends from Carrington Island northeastward, where it merges with the East Lake Fault off the southwestern tip of Promontory Point.

Our line 9 crosses the East Lake Fault just off Antelope Island and shows clear evidence of major recent displacement (Fig. 3). Correlation of our seismic profiles with sediment cores in various parts of the lake allows us to identify the sequence of sediments deposited since the rapid fall of the lake following its Bonneville phase, about $13.5 \mathrm{ka}$ (Oviatt, 1997; Kelts, K.R., Thompson, R.S., and Oviatt, C.G., unpublished data). We designate the top of the Bonneville sequence as horizon $\mathrm{B}$. The oldest post-Bonneville sediments have clearly been displaced multiple times since their deposition (Fig. 3). Detailed analysis of these and more recent data by Dinter and Pechmann $(1999 a, b)$ indicate at least three episodes of movement on each of two fault segments, totaling as much as $12 \mathrm{~m}$. The sediments thicken toward the main fault, commonly into grabens formed by antithetic faulting (Fig. 3). The sediments typically reach a maximum thickness of about $13 \mathrm{~m}$ adjacent to the fault, but recent drilling has shown that in local grabens, they may be as much as $22 \mathrm{~m}$ thick and contain significant amounts of salt.

Where the East Lake Fault merges with the Carrington Fault off Promontory Point, the pattern is more complex (Fig. 4). An overall graben-like structure is present, involving significant displacement of the uppermost sediments. In more detail (Fig. 4), the East Lake Fault clearly cuts the lake floor. Many of the faults observed in our profiles extend to, or near, the lake floor, but this is one of the few instances in which a fault has topographic expression. Our highest-resolution data (the limited $7 \mathrm{kHz}$ data from 1979) show that the youngest resolvable sediment is locally disrupted by faulting. Along the Carrington Fault, this disruption results from subsidence in a secondary graben adjacent to the fault (Fig. 5A). An example of warping of the sediment sequence, associated with the East Lake Fault, is shown in Fig. 5B.

Fig. 3. Seismic-reflection profile (boomer) across the East Lake Fault (rightmost fault in figure) off Antelope Island. Original and interpreted image are the same scale. Post-Bonneville sequence of lake sediments is shaded. Dotted lines indicate horizon B (upper), the inferred top of the Bonneville sequence, and an arbitrary lower reflection. Location shown in Fig. 2. 
(SW) $\exists W I \perp\urcorner \exists \wedge \forall Y \perp \wedge \forall M-O M \perp$
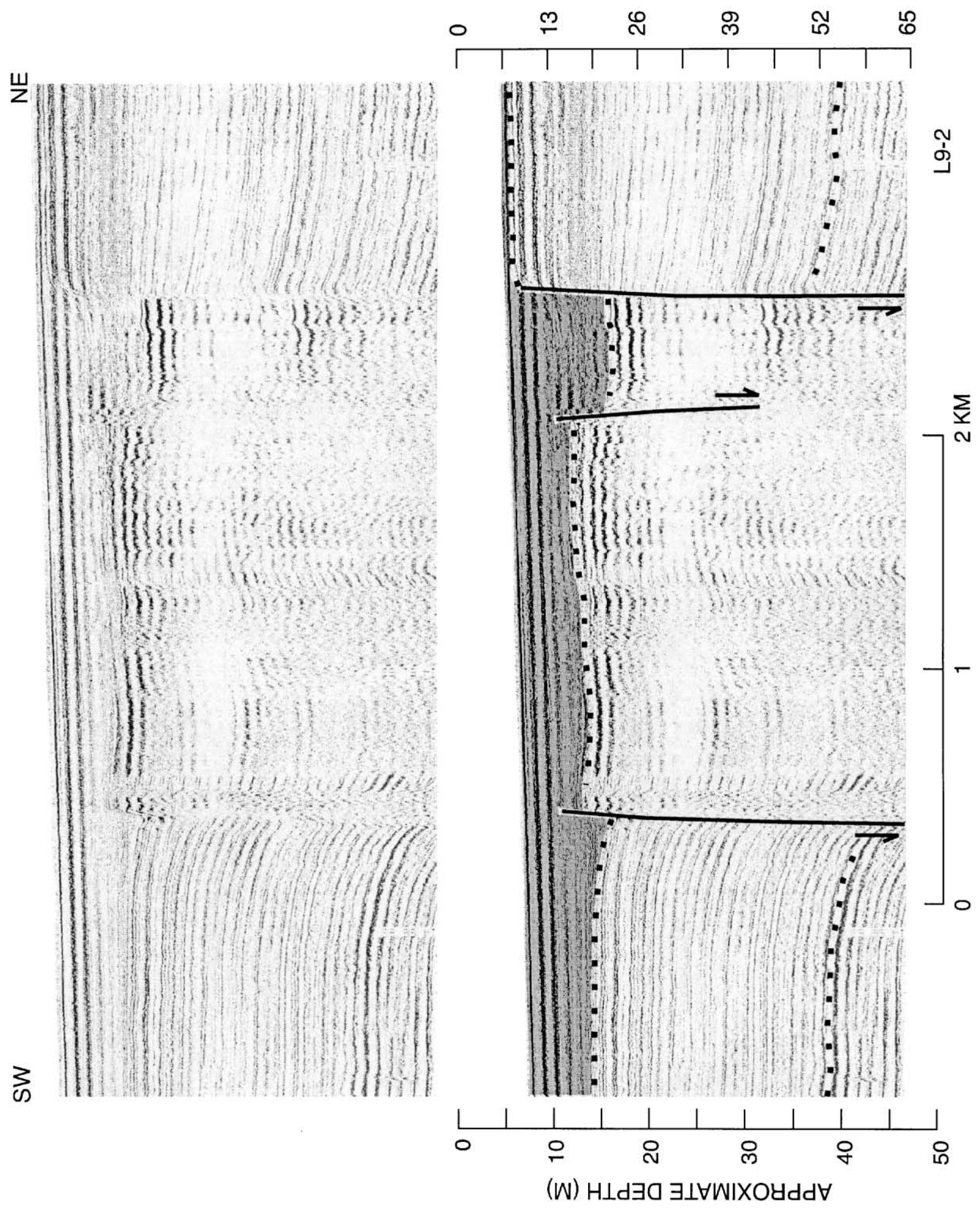


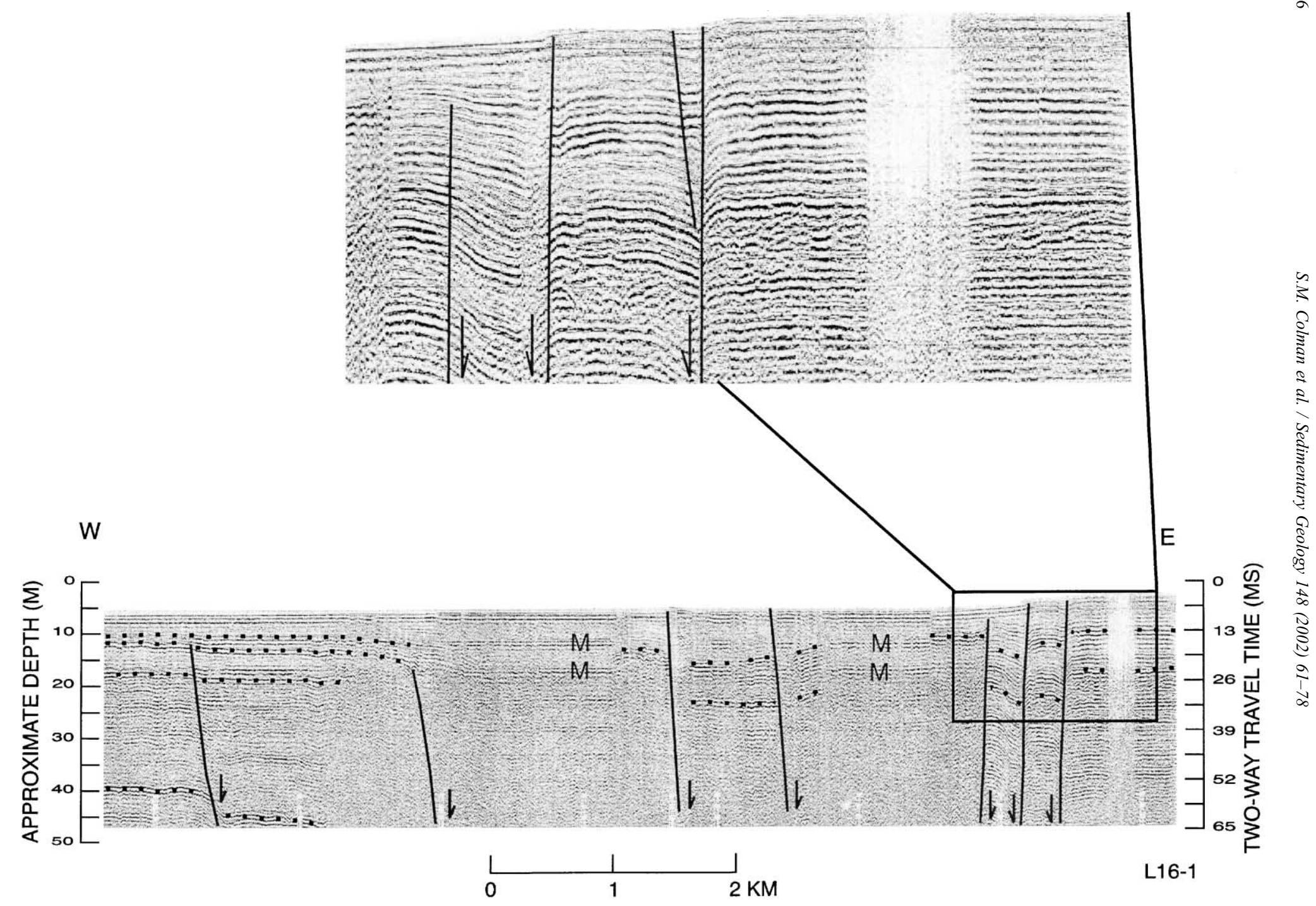

Fig. 4. Seismic-reflection profile (boomer) near the juncture of the East Lake and Carrington Faults, off Promontory Point. M, multiple reflections. Selected reflections (arbitrary) shown by dots. Location shown in Fig. 2. Detail shows section where East Lake Fault displaces the lake floor. 

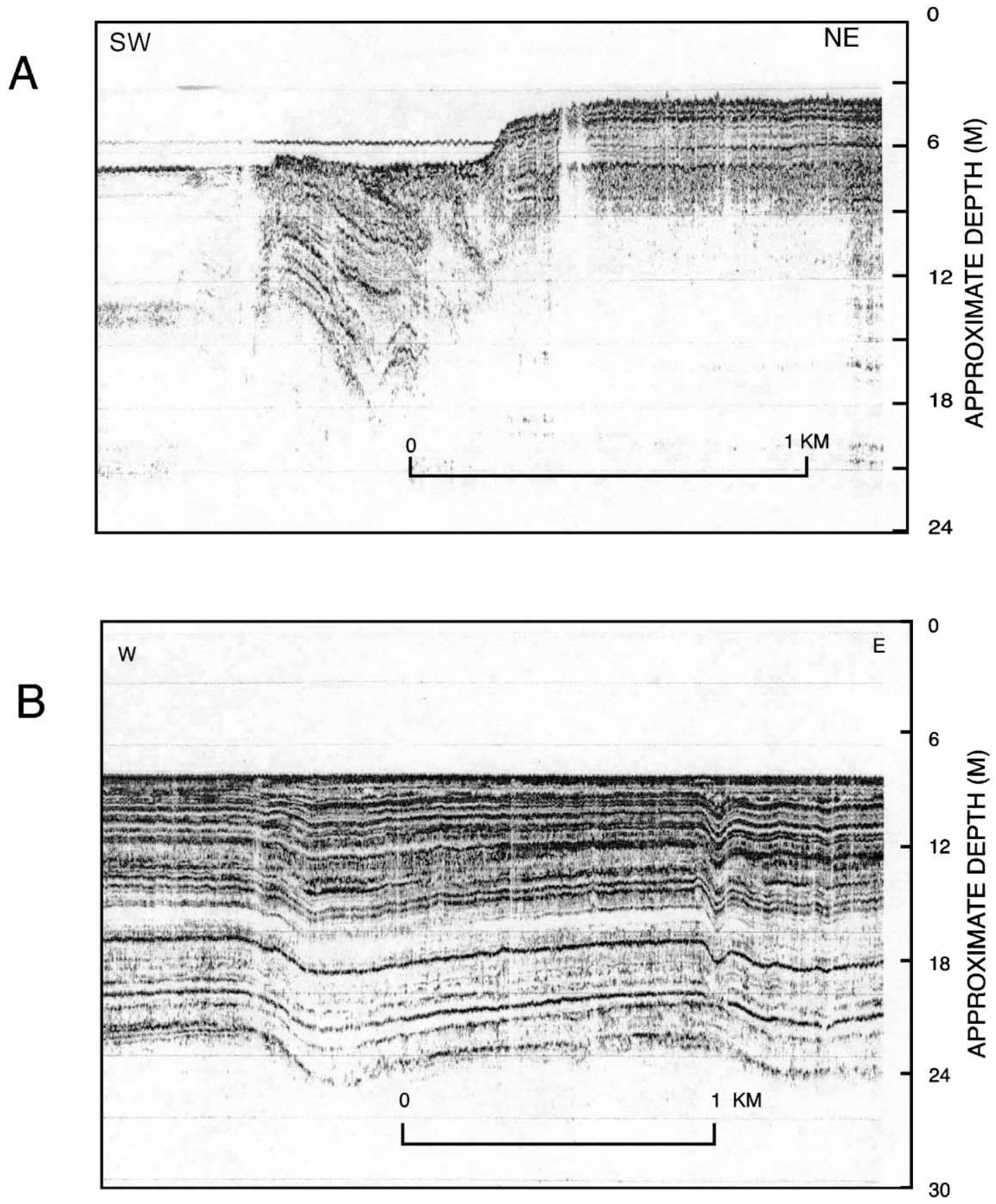

Fig. 5. Seismic-reflection profiles $(7 \mathrm{kHz})$ showing disturbance of sediments adjacent to faults. Top, Carrington Fault; bottom, secondary faults west of East Lake Fault. Locations shown in Fig. 2. 


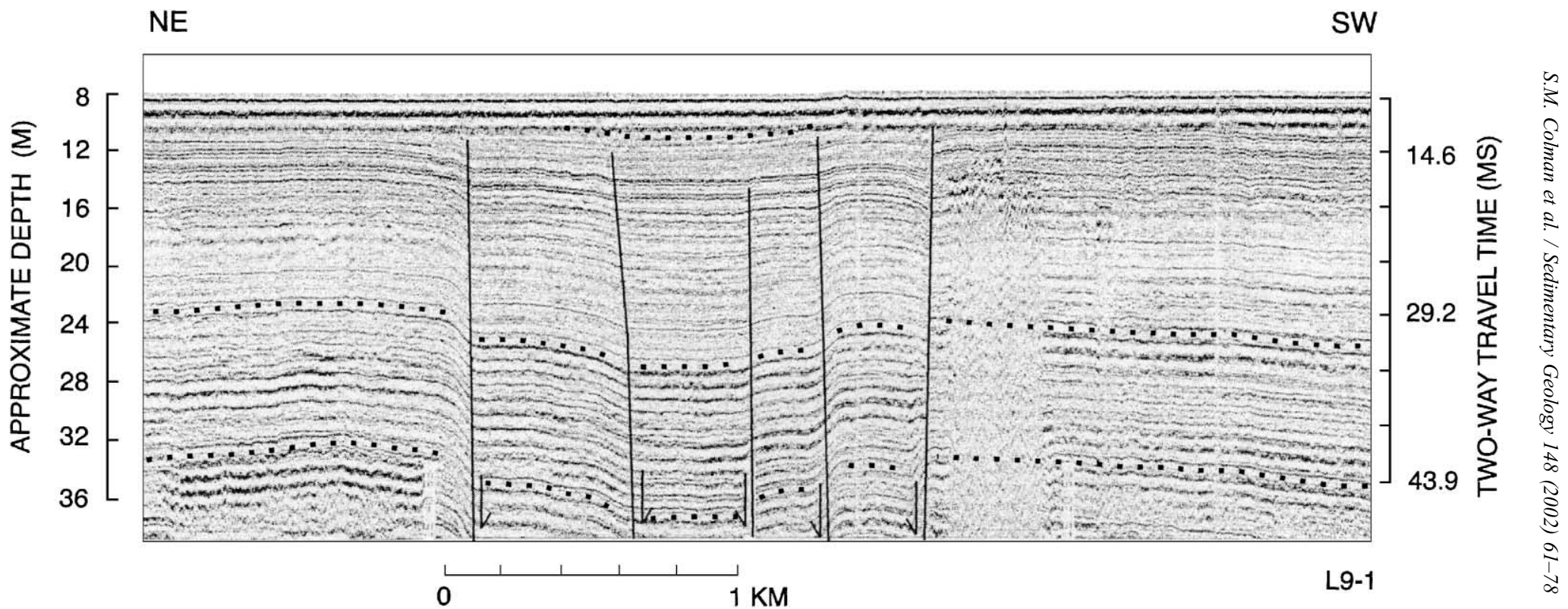

Fig. 6. Seismic-reflection profile (boomer) showing central graben in the southern basin of the lake. Selected reflections (arbitrary) shown by dots. Location shown in Fig. 2. 


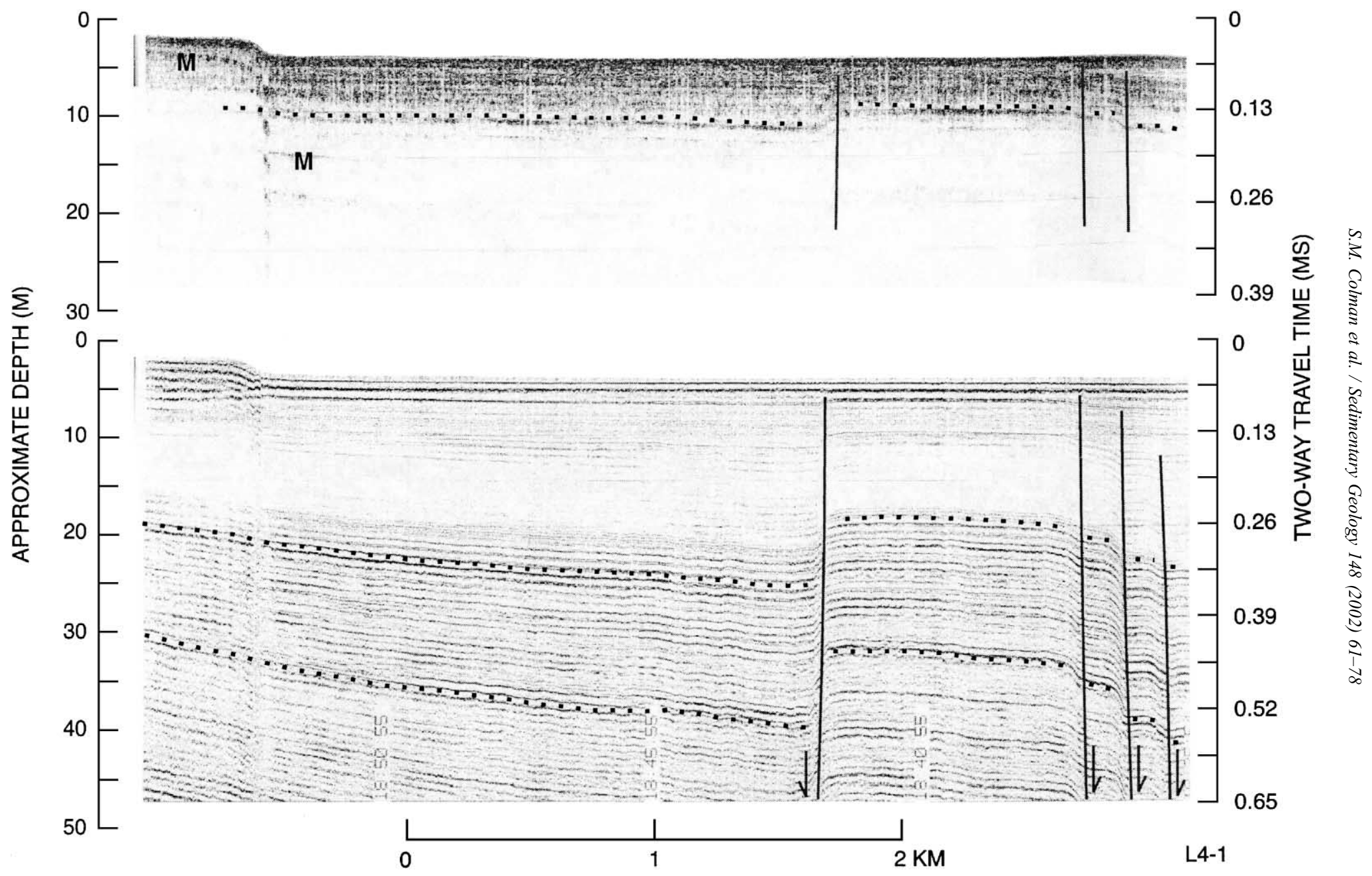

Fig. 7. Seismic-reflection profile ( $3.5 \mathrm{kHz}$, top, and boomer, bottom) showing western margin of southern basin of the lake. Note unfaulted shelf and scarp. M, multiple reflections. Selected reflections (arbitrary) shown by dots. Location shown in Fig. 2. 


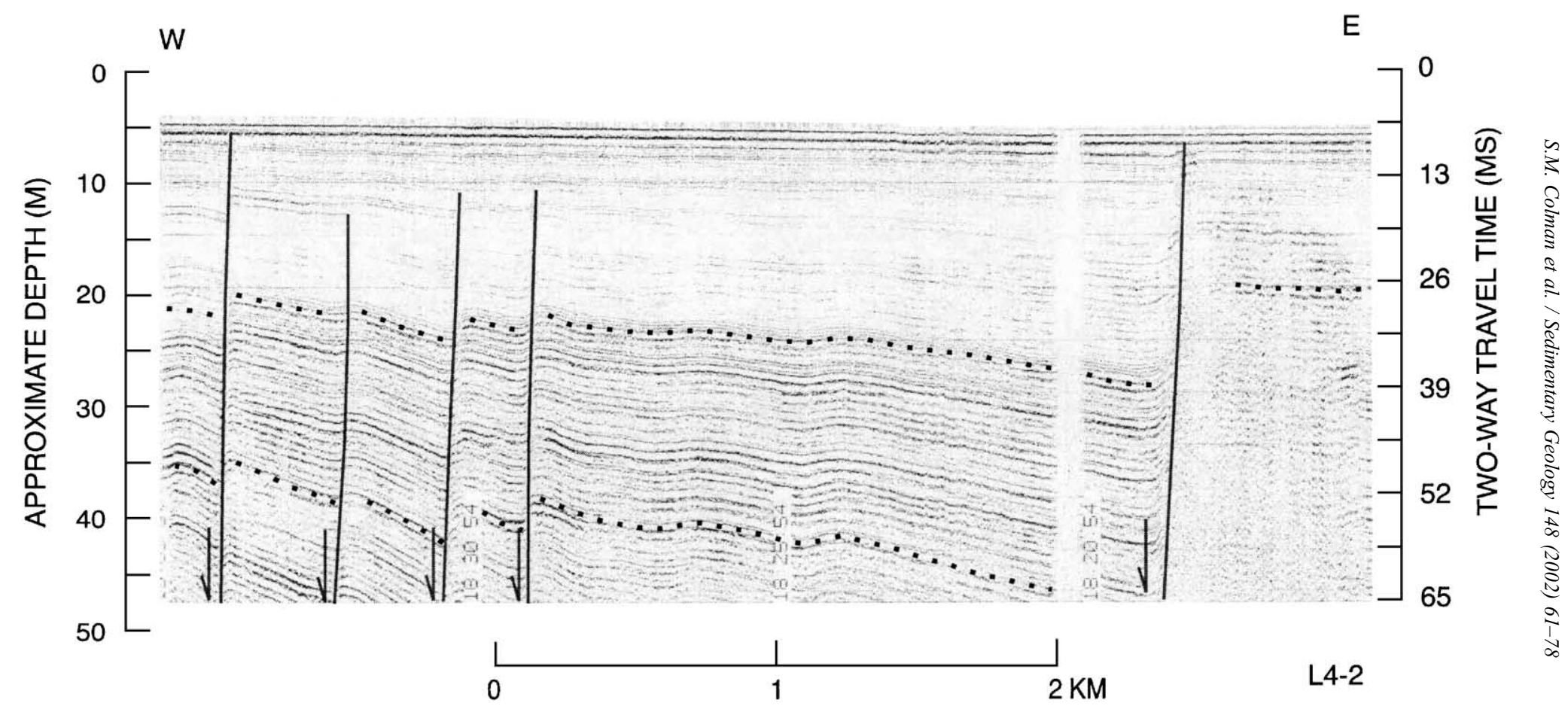

Fig. 8. Seismic-reflection profile (boomer) showing faults with upthrown sides toward the thickening sediment wedge. Selected reflections (arbitrary) shown by dots. Location shown in Fig. 2. 
A relatively well-defined graben formed by young faulting occurs along the axis of the southern basin of the lake (Fig. 6). This graben can be mapped across profiles from several of our survey lines. The graben has a relatively minor effect on the overall geometry of the sediment units. Several additional faults are found on the west side of the southern basin (Fig 7). A shallow shelf on the west side of the basin is marked by a well-defined scarp (Fig. 7), which is not related to faulting. This contrasts with the east side of the basin, where a similar scarp marks the location of the East Lake Fault. Another structural pattern that we observe in our seismic-reflection profiles is that a large number of faults, especially on the western side of the southern basin of the lake, have an unusual sense of displacement (Fig. 8). The upthrown side (foot wall) of these faults is toward the thickening wedge of sediment and toward the master fault to the east (East Lake Fault). Faults just west of the East Lake Fault are antithetic and produce the expected thickening toward the master fault. The faults described here have the opposite sense. We interpret these faults as secondary, synthetic faults related to the Carrington Fault to the west rather than the East Lake
Fault to the east. Both synthetic and antithetic faults have been observed in the AMOCO deep-seismic data by Mohapatra and Johnson (1998) who linked their formation, at least in foot wall blocks, to listric extensional movement on pre-existing thrust ramps.

The overall structural pattern formed by the two main normal faults, converging toward Promontory Point, is shown in diagrammatic cross-section in Fig. 9 and in map view in Fig. 10. The two main faults, along with the secondary antithetic and synthetic faults and the graben along the axis of the southern basin, produce a wedge of sediment that thickens distinctly toward the east. Interestingly, the floor of the lake does not show this asymmetry. Evidently, other geomorphic processes, such as sediment focussing, have acted to maintain a symmetrical east-west bathymetric cross-section in the basin.

\subsection{Stratigraphic and paleoclimatic implications}

Sediment cores obtained from the lake, first by Eardley et al. (1973), and later by Spencer et al. (1984), have been supplemented by a new set of cores taken in conjunction with this study in 1995 and 1996

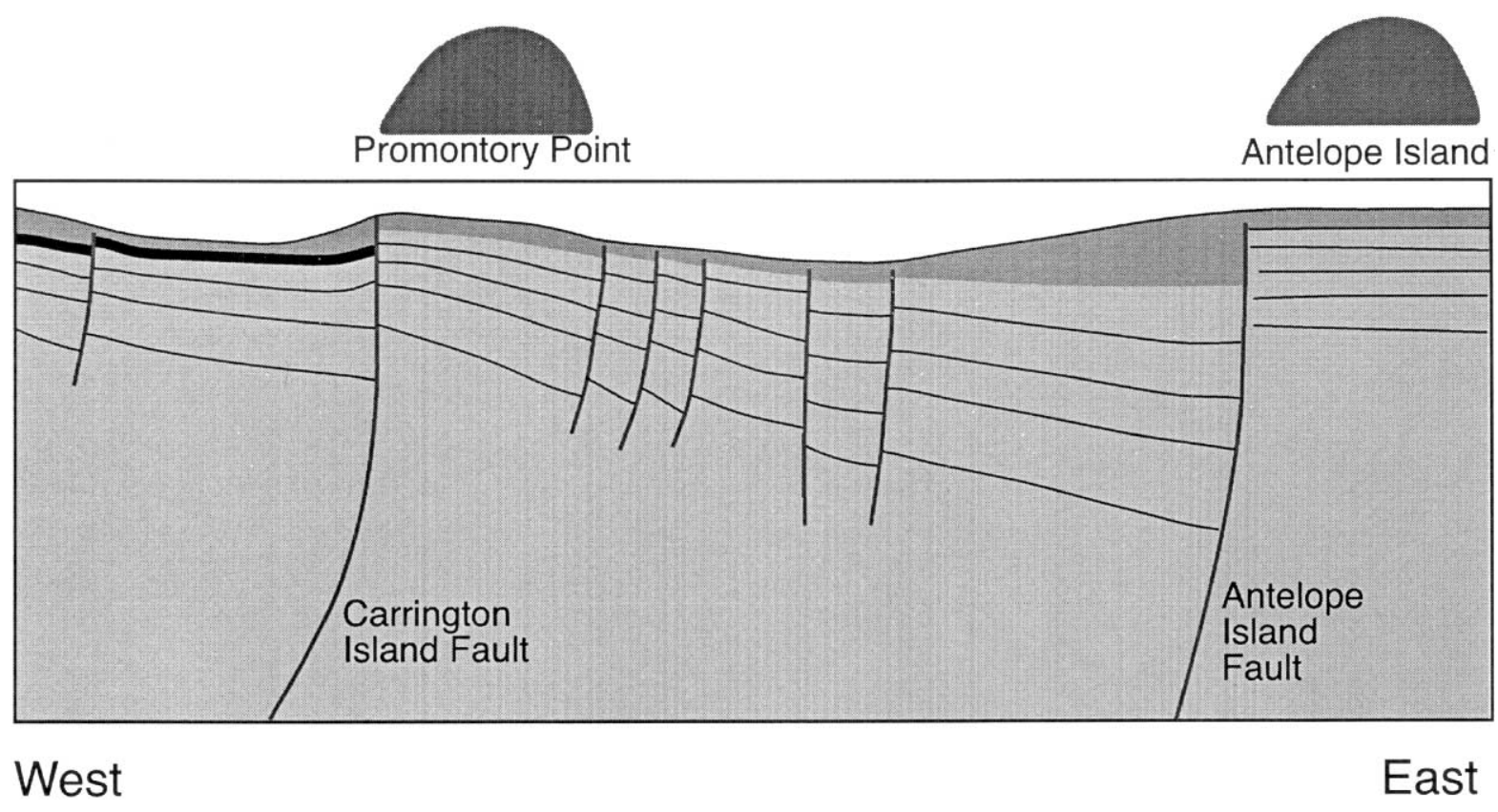

Fig. 9. Diagrammatic cross-section, approximately east-west across the middle of the southern basin of the lake. Uppermost shaded unit is the post-Bonneville sequence; dark shading indicates the mirabilite unit. 


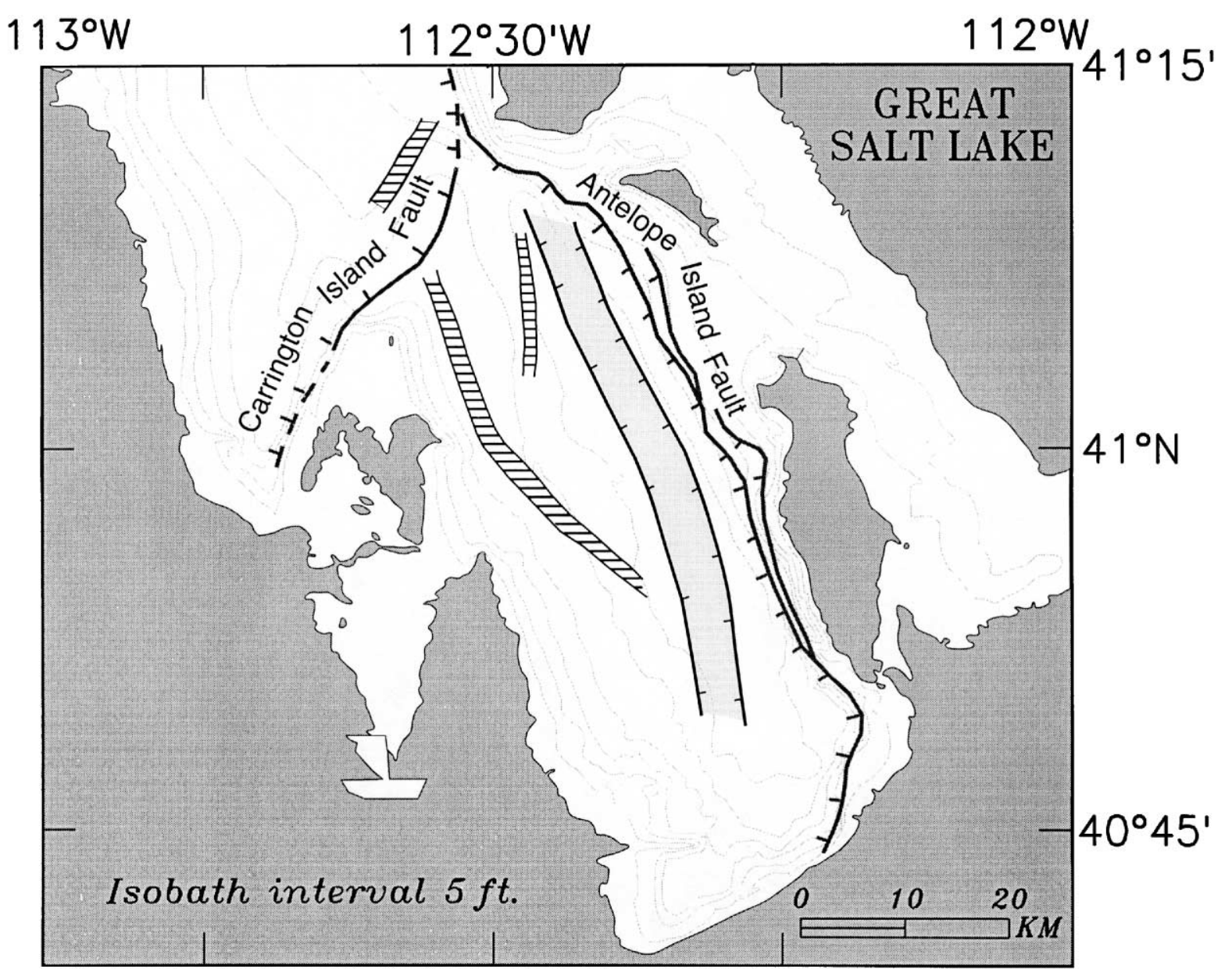

\section{$\perp \quad$ Major normal faults I' Minor graben Zone of synthetic faults}

Fig. 10. Map showing structural features discussed in the text.

(Kelts, K.R., Thompson, R.S., and Oviatt, C.G., unpublished data). The geometric and stratigraphic information in our seismic data can be correlated with the chronologic and lithologic data from sediment cores located near our survey lines (Fig. 2). We focus on core C of Spencer et al. (1984), which occurs on the seismic line shown in Fig. 11, and core 96-6, which is the subject of ongoing investigations; locations are shown in Fig. 2. In the published description of core $\mathrm{C}$, the depth scale is a composite of a gravity core and two piston cores. Because of the uncertainties involved in the composite, we used the original, unpublished depths for one of the piston cores (GSL79-7-P3).

A well-defined, continuous seismic reflector (Fig. 11), here called horizon B, appears to correlate with the top of a sediment sequence (mostly calcareous muds) deposited during the high Bonneville phase of the lake (Oviatt, G.C., written commun., 1998), which reached its maximum about $15 \mathrm{ka}$ (Oviatt, 1997). The upper- 


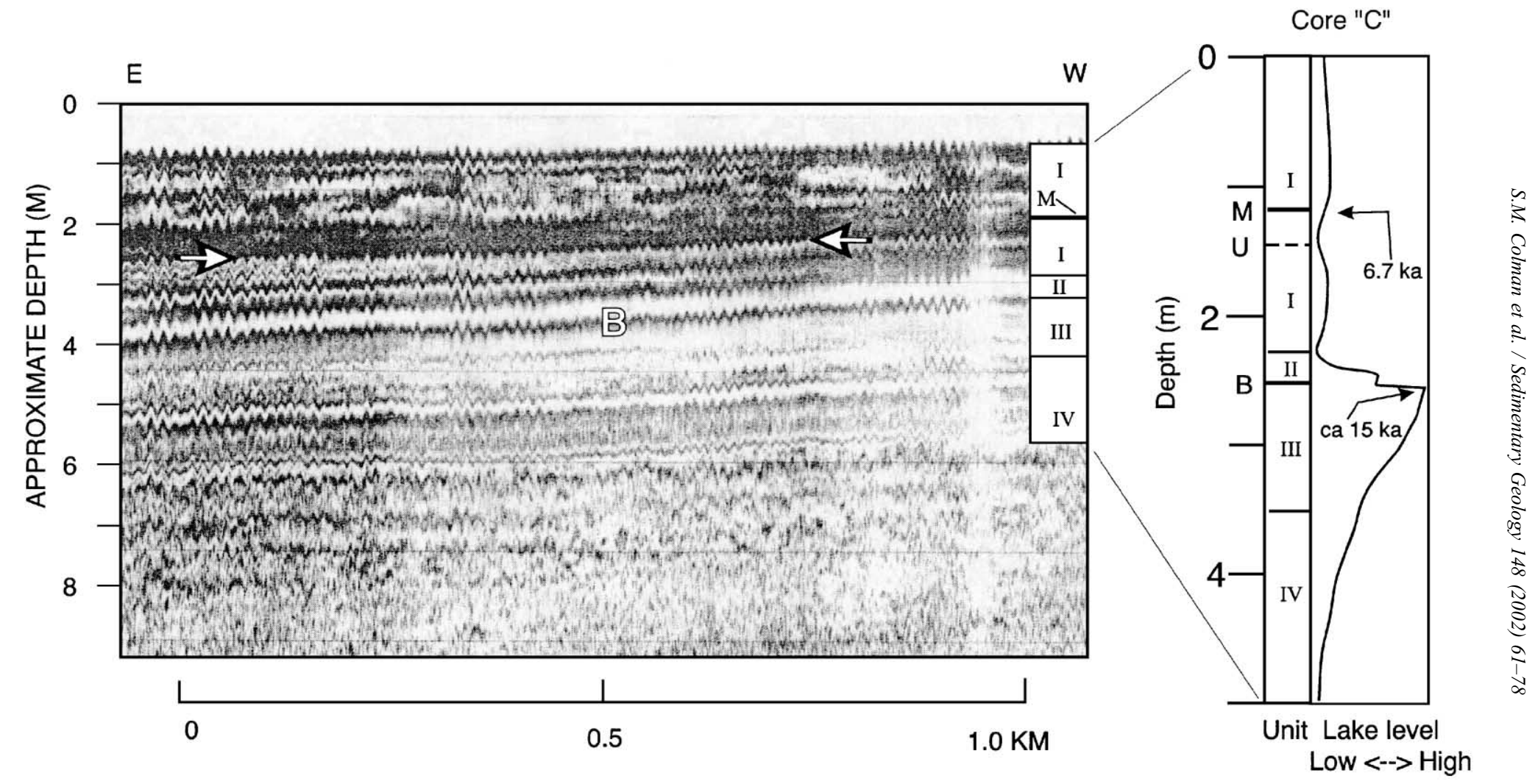

Fig. 11. Seismic-reflection profile (7 kHz) showing comparison with generalized stratigraphy (lithologic units I, II, III, IV) in Core C of Spencer et al. (1984), modified as discussed in the text. M, Mazama tephra; B, horizon B, top of Bonneville-sequence; $\mathrm{U}$ and arrows, mid-Holocene unconformity. Lake-level interpretation of Core $\mathrm{C}$ stratigraphy (this paper) is also shown. Location shown in Fig. 2. 
most part of the calcareous muds (unit III of Spencer et al., 1984) is characterized by reworked, mud-coated ostracodes, which we interpret as being related to the rapid fall of the lake from the Bonneville to the Provo level shortly after $15 \mathrm{ka}$. This unit is overlain by a few tens of centimeters of finely laminated mud that mark the transition to a low lake stage by about $13.5 \mathrm{ka}$. We infer that seismic horizon $\mathrm{B}$ corresponds to the unit
III-unit II boundary of Spencer et al. (1984) and essentially marks the top of sediments of the Bonneville high lake phase.

Uncertainties in the correlations between the seismic and sediment-core data would also allow a correlation to the unit I-unit II boundary (unit II is commonly only a few tens of centimeters thick) or a double reflection on either side of unit II. Horizon B

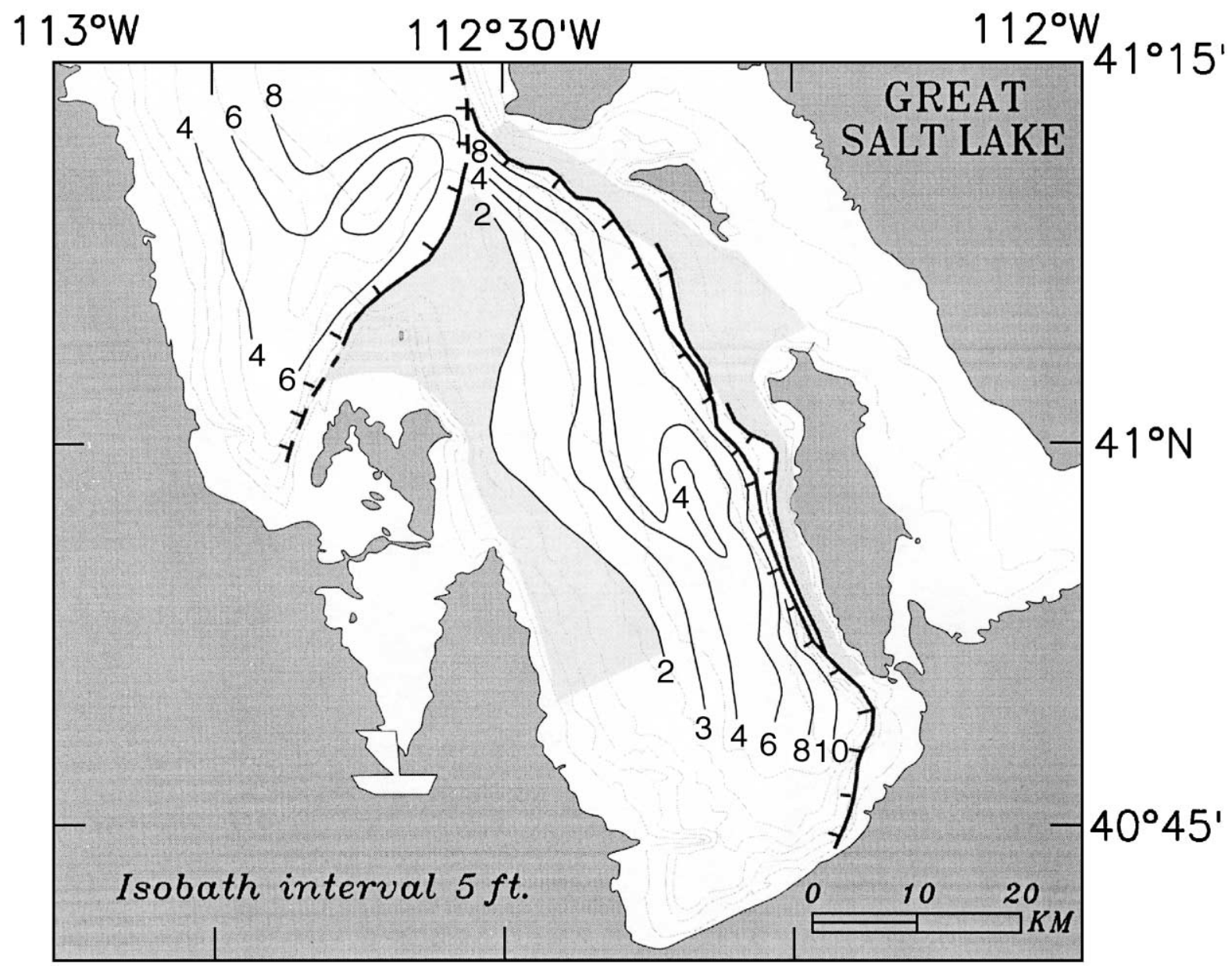

$\perp \quad$ Major normal faults

- 4 Isopachs $(\mathrm{m})$ of post-Bonneville sediment sequence Areas where post-Bonneville sequence is $<2 \mathrm{~m}$ thick

Fig. 12. Isopach map of the post-Bonneville sequence of sediments in the lake. 
can be traced throughout the southern basin of the lake and throughout the part of the northern basin covered by our data (south of the causeway). Thus, we can map the distribution and thickness of post-Bonneville sedi- ments throughout the southern part of the lake (Fig. 12). The sequence thickens toward the center of the southern basin, such that horizon B occurs at $250 \mathrm{~cm}$ at core $\mathrm{C}$ and at $460 \mathrm{~cm}$ at core 96-6 (locations shown

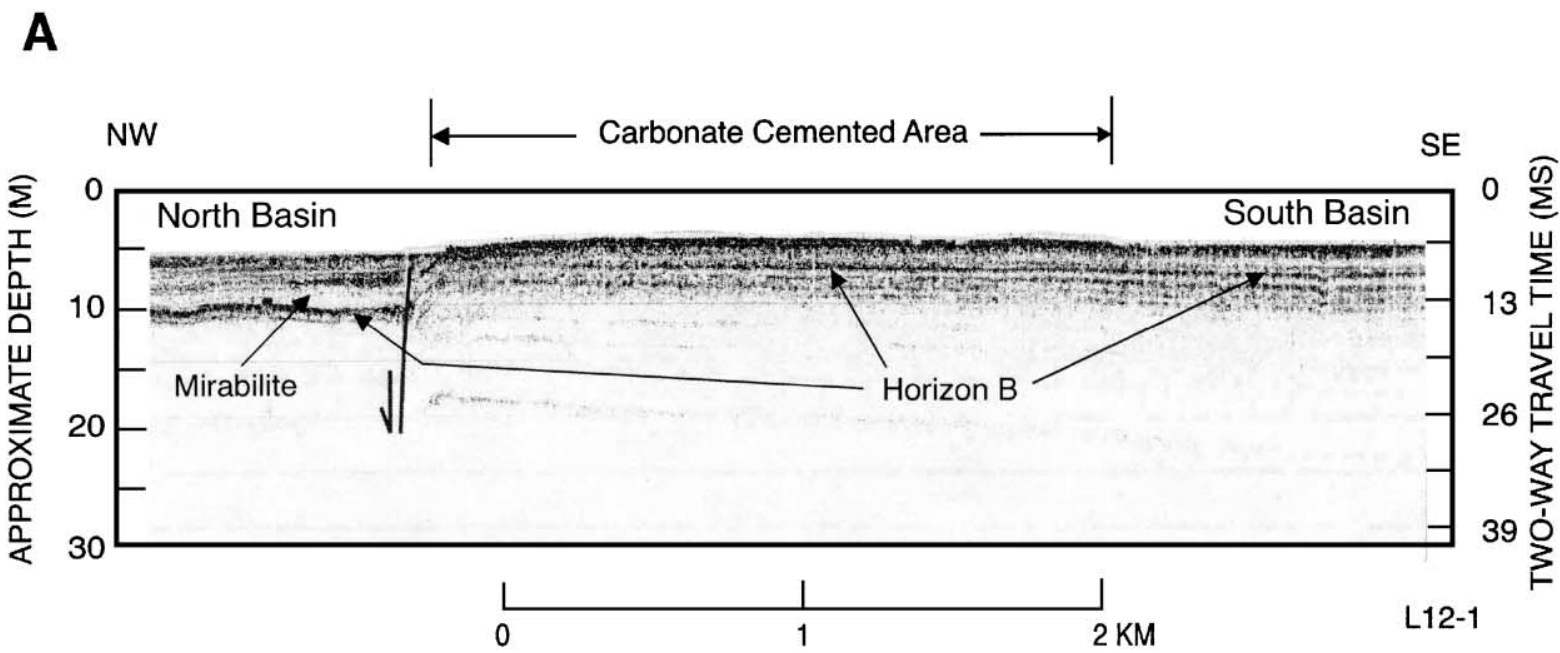

B

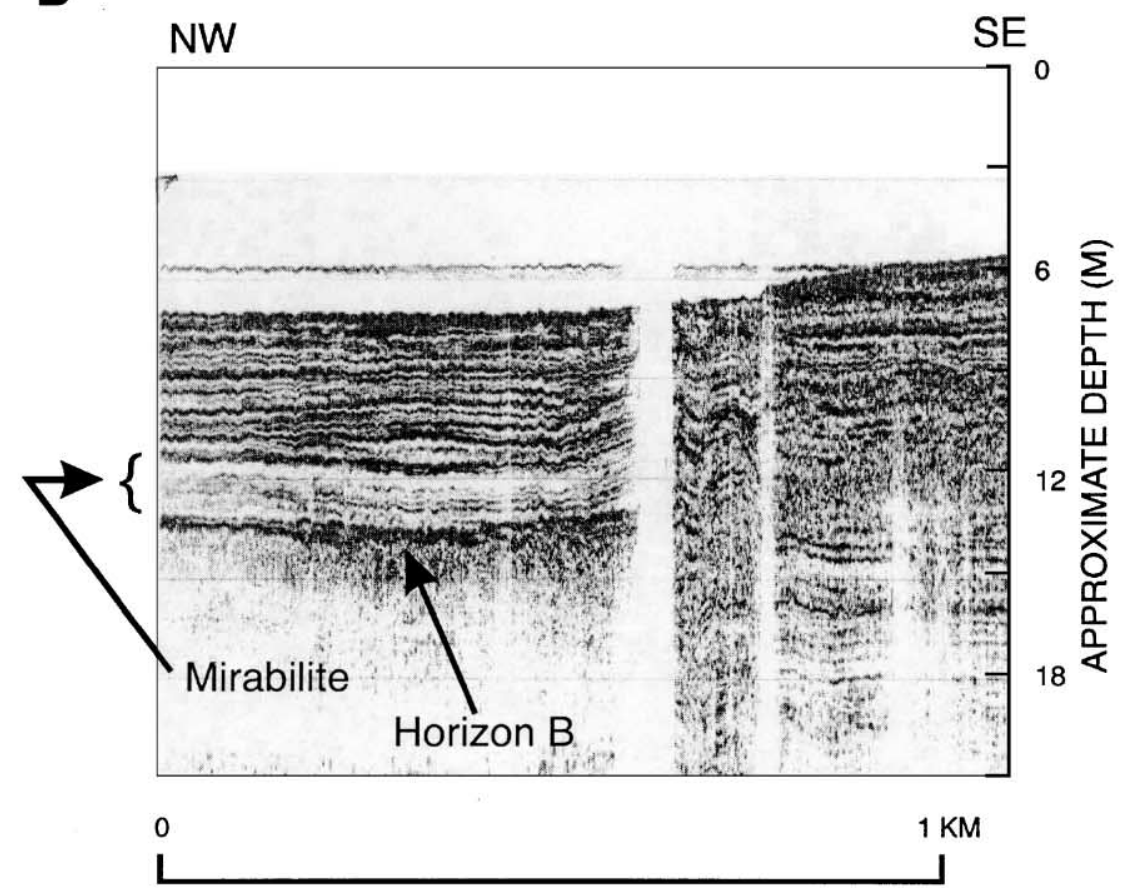

Fig. 13. Seismic-reflection profiles (A, $3.5 \mathrm{kHz} ; \mathrm{B}, 7 \mathrm{kHz}$ ) showing the sill separating the northern basin of the lake from the southern basin, and the mirabilite unit northwest of the sill. Horizon B is the top of the Bonneville sequence. Reflection in the water column on the northwest side of $\mathrm{B}$ is the top of brine in the northern basin. Location shown in Fig. 2. 
in Fig. 2). It thins to zero along the ridge between Carrington Island and Promontory Point.

A seismic reflector appears to correlate consitently with the Mazama tephra (ca. $6.7 \mathrm{ka}$, Hallet et al., 1997) in cores where this tephra has been identified (Fig. 11). At this horizon, underlying reflectors are locally truncated at a very slight angle (Fig. 11). We interpret this unconformity to be the result of an early Holocene low lake stand, one significantly lower than present. Although no channeling or shoreline features were observed and the stratigraphy in the center of the basin is undisturbed, we infer that the lake basin was dry, or nearly so. An intermittently inundated playa environment would explain the dolomite at the top of unit III of Spencer et al. (1984) and the thin collapse breccia observed in some cores. During this time, pools of brine may have persisted in local graben depressions adjacent to the fault, and additional details of the lowstand may be recorded in sediments there. The $13 \mathrm{~m}$ of post-Bonneville salt recently observed in drilling at one location along the East Lake fault suggests the possibility of such a record. The unconformity related to this low lake phase is indistinguishable from the horizon correlated with the Mazama tephra, so that the tephra may have been deposited on the playa surface at the time of the low lake stand. This interpretation is consistent with the presence of reworked Mazama tephra in several cores.

The ridge between Carrington Island and Promontory Point, on the upthrown side of the Carrington Fault (Fig. 13), is capped by a carbonate-cemented pavement (Spencer et al., 1984). We infer that the carbonate-cemented surface of the ridge formed during the early Holocene low lake phase, as may some of the bioherm mounds observed below present lake level. The ridge separates the northern and southern basins of the lake, which differ in hydrology and water chemistry. A thick layer of mirabilite occurs beneath the northern basin and is thought to have been deposited as the lake rapidly fell from the Provo level (Eardley, 1962; Eardley et al., 1973; Spencer et al., 1984). Seismic profiles near cores in which mirabilite was found exhibit an acoustically transparent layer about $2 \mathrm{~m}$ thick (Fig. 13), which we infer to be the mirabilite bed.

The seismic profiles show the presence of mound structures on the basin floor throughout the lake (Fig. 14). In many cases, the mounds appear rooted in the Holocene sediments, and they are commonly associ-

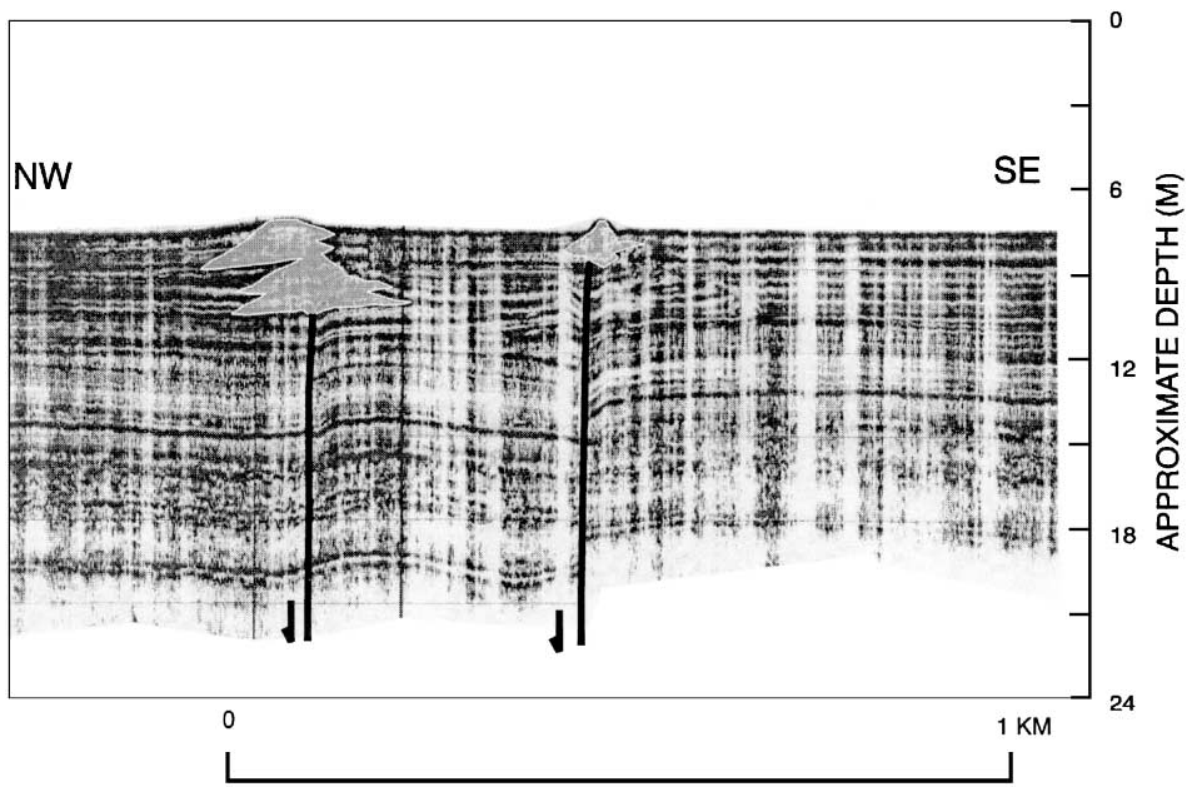

Fig. 14. Seismic-reflection profiles $(7 \mathrm{kHz})$ showing inferred bioherm mounds (shaded) atop fault planes. Location shown in Fig. 2. 
ated with faults. We interpret these mounds to be bioherms, similar to those around the shore of the lake. Those that occur above faults may have formed by enhanced carbonate precipitation where basinal fluids migrated up along fault traces.

\section{Conclusions}

Seismic profiling combined with coring provides the tools for improving our understanding of several aspects of the history of Lake Bonneville and the Great Salt Lake, including sedimentation patterns, lake-level changes, and the distribution and recurrence of recent fault movements. The basin has been, and continues to be, an area of active extensional tectonics that have a major effect on the distribution and type of sediments in the lake. The East Lake Fault appears to be at least as active as any of those along the Wasatch Front, having at least three episodes of significant faulting since lake level fell from its Pleistocene high about $13.5 \mathrm{ka}$. The upthrown side of the Carrington Fault forms a sill which is only about $5 \mathrm{~m}$ below present lake level and which separates the lake into two different hydrologic units. Fluid flow into the lake along fault planes may explain some of the bioherm mounds present on the lake floor.

Fall of the lake to low levels about 13,500 ka, after the high Bonneville phase, led to the formation of a basin-wide horizon (horizon B) that can be traced in our seismic-reflection data. This reflector allows the pattern of subsequent sediment deposition in the lowlevel lake to be determined. The pattern in the southern basin is a distinct wedge thickening toward the East Lake Fault, contrasting to some degree with the smooth symmetry of the modern lake bathymetry. Lake level appears to have been considerably lower than present during the early Holocene, including the time of deposition of the Mazama tephra, resulting in a subtle angular unconformity in the lake sediments. During this time, the lake basin may have been an intermittently flooded playa, with small remnant water bodies in grabens along the active fault. The Mazama tephra was apparently deposited on this playa surface, which may explain the common occurrence of reworked Mazama tephra in the overlying sediments.

\section{Acknowledgements}

We thank Dave Nichols for his invaluable help in collecting the data in the field. Chris Lueke and Wayne Wurtzbaugh of the Department of Fish and Wildlife at Utah State University provided us with their research vessel for the 1997 survey, and the staff of Antelope Island State Park helped with logistics for all of the surveys. Helpful reviews were provided by Chris Scholz, Geoff Seltzer, and Rob Thieler. Various phases of this work were supported by the Global Change and Climate History (now Earth Surface Dynamics) Program of the U.S. Geological Survey, the Earth System History Program of the National Science Foundation, and the Swiss Nationalfond.

\section{References}

Arabasz, W.J., Smith, R.B., Richins, W.D. (Eds.), 1979. Earthquake Studies in Utah, 1850-1978. University of Utah Seismograph Stations Special Publication, Salt Lake City.

Colman, S.M., Kelts, K.R., 1997. Evidence for neotectonics and climate change from high-resolution seismic stratigraphy of Great Salt Lake, Utah. Geological Society of America Abstracts with Programs 29 (6), 253.

Davis, O.K., Moutoux, T.E., 1998. Tertiary and Quaternary vegetation history of the Great Salt Lake, Utah. Journal of Paleolimnology $19,417-427$.

Dinter, D.A., Pechmann, J.C., 1999a. Sublacustrine paleoseismology: evidence for recent earthquakes on the East Great Salt Lake Fault, Utah. Association of Engineering Geologists, Abstract, $62-63$.

Dinter, D.A., Pechmann, J.C., 1999b. Multiple Holocene earthquakes on the East Great Salt Lake Fault, Utah: evidence from high-resolution seismic reflection data. EOS, Transactions of the American Geophysical Union 80, F734.

Eardley, A.J., 1962. Glauberís salt bed west of Promontory Point, Great Salt Lake. Utah Geology and Mineral Survey, Special Studies 1, $12 \mathrm{pp}$.

Eardley, A.J., Shuey, R., Gvodetsky, V., Nash, W.P., Picard, M.D., Grey, D.C., Kukla, G.J., 1973. Lake cycles in the Bonneville basin, Utah. Geological Society of America Bulletin 84, 211-215.

Gilbert, G.K., 1890. Lake Bonneville. U.S. Geological Survey Monograph 1, $275 \mathrm{pp}$.

Hallet, D.J., Hills, L.U., Clague, J.J., 1997. New accelerator mass spectrometer radiocarbon ages for the Mazama tephra layer from Kootenay National Park, British Columbia, Canada. Canadian Journal of Earth Sciences 34, 1202-1209.

Kowalewska, A., Cohen, A.S., 1998. Reconstruction of paleoenvironments of the Great Salt Lake basin during the late Cenozoic. Journal of Paleolimnology 20, 381-407.

Mikulich, M.J., Smith, R.B., 1974. Seismic reflection and aeoromagnetic surveys of the Great Salt Lake, Utah. Geological Society of America Bulletin 85, 991-1002. 
Mohapatra, G.K., Johnson, R.A., 1998. Localization of listric faults a thrust fault ramps beneath the Great Salt Lake basin: Utah: evidence from seismic imaging and finite element modeling. Journal of Geophysical Research 103, 10047-10063.

Oviatt, C.G., 1997. Lake Bonneville fluctuations and global climate change. Geology 25, 155-158.

Pechmann, J.C., Nash, W.P., Viveiros, J.J., Smith, R.B., 1987. Slip rate and earthquake potential of the East Great Salt Lake fault, Utah. EOS, Transactions of the American Geophysical Union $68,1369$.
Smith, R.B., Bruhn, R.L., 1984. Intraplate extensional tectonics of the eastern Basin-Range: inferences on structural style from seismic reflection data, regional tectonics, and thermal-mechanical models of brittle-ductile deformation. Journal of Geophysical Research 89, 5733-5762.

Spencer, R.J., Baedecker, M.J., Eugster, H.P., Forester, R.M., Goldhaber, M.B., Jones, B.F., Kelts, K., Mckenzie, J., Madsen, D.B., Rettig, S.L., Rubin, M., Bowser, C.J., 1984. Great Salt Lake, and precursors, Utah: the last 30,000 years. Contributions to Mineralogy and Petrology 86, 321-334. 